\title{
POSITIVE AND NEGATIVE FACE ON ALVIN ADAM'S UTTERANCES ON JUST ALVIN TALK SHOW
}

\author{
Agustina Lestary \\ STKIP PGRI Banjarmasin \\ Jln. Sultan Adam Kompleks H. Iyus, No. 18 RT. 23 Banjarmasin, \\ Kode Pos 70121. \\ Email: agustinalestary@ stkipbjm.ac.id
}

\begin{abstract}
Talkshow combines entertainment and information at once and it offers more than just a monotonus story. Host has important role in a talkshow. Thus it is essential for the host to apply certain strategies when they are interviewing the guests. Alvin Adam has interviewed many public figures from celebrities to paranormal in his Sunday night program called Just Alvin. In this paper, the writer takes the episode of Miss No Comment of Just Alvin. The guest of this show is one of Alvin's close friends Desi Ratnasari. The writer identifies several postivie politeness strategies applied by Alvin during the programe. Alvin will use positive face strategies to give express his solidarity to Desi as he is also part of Desi's life and will use negative face strategies to show that he knows nothing about Desi's life.
\end{abstract}

\section{Introduction}

Nowadays, talk show is one of popular shows in television program. Talk show can be described as a program that offers entertainment and information at the same time. It gives entertainment since viewers can find funny, interesting or even melodramatic stories in 30-minuteto-60-minute show. It also gives information to the viewers as the host will ask many questions to the guests in which the answers might be new ideas or perspectives for the viewer themselves.

Even though talk show itself is a scripted show, in terms of the hosts have already prepare the questions beforehand, but the host still needs to do certain strategies and approaches to get the guests talk comfortably. Thus, it is important for the hosts to know how to make the guests talk as much as possible regarding the topic asked by the hosts. Since talk show concept is quite similar to natural conversation, then it is acceptable to expect that there will be several phenomenon of pragmatics occur in talk show.

This paper is intended to describe the strategy of face wants used by host of an Indonesian Talk Show named Just Alvin. This show is broadcasted on every Sunday night for 30 minutes. The guests are varied; from singers, actors/actresses, models, to 'paranormal'. The setting of the show is in TV Studio in which there are two sofas for the host and the guests. The talk show itself is hosted by Alvin Adam. 


\section{Theoretical Framework}

The theoretical framework will explain the theory regarding the pragmatic phenomenon described in this paper and also how the phenomenon is related to the nature of talk show. This part will be divided into two parts; face wants and the fundamental elements on talk show.

\section{Face Wants}

Levinson and Brown (1987) classified face wants is part of positive politeness. Face wants relates closely to how speakers produce utterances that will show positive face or negative face of the hearers. If the speakers want the hearers to be part of the speakers, then the utterances produced should show positive face. On the other side, the negative face utterances chosen if the speakers want to be independent or separated from the hearers. There are several strategies of positive and negative face classified by Levinson\&Brown.

\section{Positive Face Strategies}

Positive face is the want of every member that his wants be desirable to at least some others. (Levinson\&Brown: 61)

1. Notice, attend to hearer $(\mathrm{H})$ (his interest, wants, needs, goods)

2. Exaggerate (interest, approval, sympathy with $\mathrm{H}$ )

3. Indicate $\mathrm{S}$ know H's wants and is taking them into account

4. Use in-group identity markers

5. Presuppos/raise/assert common ground

6. Be optimistic

7. Assume or assert reciprocity

8. Use given names and nicknames

\section{Negative Face Strategies}

Negative face is the want of every 'competent adult member' that his actions be unimpeded by others (Levinson\&Brown: 62, 1987).

1. Make minimal assumptions about H's wants

2. Give $\mathrm{H}$ the option not to do the act 
3. Minimize threat

\section{Apologize}

5. Be pessimistic

6. Dissociate $\mathrm{S}$ and $\mathrm{H}$ from the discourse

7. State a general rule

8. Use family names and titles

\section{Research Method}

The data of this paper was 17 minutes of 30 minutes Just Alvin talk show on Miss No Comment episode. The data was taken from a popular video broadcasting website, youtube.com. The video that has been downloaded then transcribed. This research used qualitative approach. The transcribed data was classified into several categories along with the discussion what the certain data was placed into certain categories.

\section{Findings and Discussion}

As the host of a talk show, Alvin puts himself in two positions. Some times he will act as the host who would like to get certain information by putting the negative face and there are times when he acts as a close friend by putting the positive face in order to show solidarity to the guest. Here are the strategies used by Alvin during the talk show.

\section{1) Positive Face}

From the show, it can be seen that Alvin has already known Desi personally for a quite long time. Alvin, then, used his closeness to Desi to make Desi comfortable in sharing her thoughts and answering Alvin's questions. Here are several strategies of positive face used by Alvin during the show.

1. Giving attention.

Alvin opened the show by giving attention to Desi's physical appearance as he complimented her looks.

(1) Alvin : Kamu makin cantik, makin langsing, makin fresh

Alvin : Pretty in pink, ya?

2. Exagerate 
Alvin showed how he was interested on certain topic by saying it directly.

(2) Alvin : Nah ini saya tertarik

Before this utterance was produced, Desi stated that she was quite close to her mother's family but not really close to her father's. Alvin's interest opened a new discussion on why the situation Desi described happened.

3. Claim common point of view, opinions, attitude

Alvin tried to show the opinion on how time has flied so fast and there were many things that had happened during the duration of time. Desi agreed with Alvin as by stating the exact duration of time.

(3) Alvin : : Waktu cepat sekali, ya, Des.

Desi $\quad: 10$ tahun.

This positive face act opened the discussion about Desi's daughter. In another part of the talk show, Alvin showed common opinion with Desi.

(4) Desi

: .... jadi kadang-kadang kalo saya lagi sendiri saya suka butuh, "aduh kayaknya pengen ada mas Irwan di sebelah saya" tapi ga ada. Jadi, akhirnya itu membentuk saya untuk selalu prepare, kan? Udah jangan ngarepin orang deh, kamu bisa kok sendiri! Udah jangan ngarepin orang.

Alvin $\quad$ : Terbiasa sendiri.

Desi : He'eh, kalo kata orang Sunda mah, *'Sa kasamperna. Lamun ka samper nya hayuk aya. Kalo ga kasamper ya ga usah" gitu ga pa pa. Lu sendiri juga bisa. Na, kemudian, yang sebelumnya saya tidak menjadi diri sendiri itu adalah bahwa saya berusaha untuk membuat orang lain bahagia.

Desi tried to describe her situation and her feeling and Alvin showed that he had the same opinion with Desi regarding his feeling by concluding Desi's previous utterances.

4. Claim in group membership

Alvin showed Desi that he was in the same group as her in terms that he knows what Desi was trying to explain.

(5) Desi : ..... Karena saya daily life saya setiap hari itukan kalo dulu setiap hari sama nenek saya

Alvin : Kita foto bareng jaman 25 tahun yang lalu aja ya.. selalu nenek nganterin kemanapun

Desi : He'eh, ikatan batin.. 
Desi told that she was close to her grandmother to the extent that her grandmother was part of her every day activities. At this moment, Alvin showed he was part of Desi's life by stating that he knew her since years ago and he also saw by himself how close Desi to her grandmother was.

\section{Be optimistic}

Alvin naturally said his assumptions about Desi's feeling or situations as if he really knew what she felt. Desi, in the other hand, agreed with Alvin's assumptions.

(5) Alvin : Dekat tapi mandiri, ya?

Desi : Iya. Harus atuh. Saya kerja. Kalo anak saya ga mandiri ehooo ntar gimana.

Alvin: Tapi dari kecil memang dibiasakan bahwa dia harus face it bahwa memang situasi kayak begini.

Desi : Betul. Saya mengajarkan itu dari awal ketika.. ngomongin masa lalu saya ya?

In the first utterance, Alvin stated his opinion about the relationship between Desi and her daughter. Alvin believed that Desi and her daughter are close but independent. Desi instantly agreed with Alvin's assumption. In place of Alvin, it was Desi who explained Alvin's previous assumption as she told why her daughter should be independent.

\section{2) Negative Face}

Besides showing positive face, Alvin also showed negative face as an attempt to put himself outside Desi's life. In some of his utterances, Alvin acted as if he was a stranger and did not know anything about Desi.

1. Make minimal assumptions

Alvin would make minimal assumptions by using unfinished utterances or questions. For example:

(6) Alvin : Tapi frekuensi dia bertemu dengan ayah kandungnya....

Desi : Agak jarang.. jarang..

(7) Alvin : Is it hurt you at the moment?

Desi : Ya, gitu aku ga enak lah.

On the first example, Alvin used unfinished utterance since he did not know the situation in Desi's life and the relationship between Desi's daughter and her father. Thus, he wanted Desi to finish his line by telling the real situation, instead of making his own assumption and 
telling it to Desi. On the second example, Alvin probably did not know Desi's real feeling so he could not not make any assumption, and asked it directly instead. Alvin's question lead to a discussion about Desi's childhood life.

2. Give hearer the option not to do the act

As a host, Alvin realized that there are some matters that are probably too personal and too private to be brought in a discussion. Thus, before proceeding to another topic which in Alvin's opinion is quite sensitive, he asked Desi's agreement beforehand. For example:

(8) Alvin : Di sini kita tanya boleh ya?

Desi : Boleh.....

Desi could say "yes" if she did not mind talking about the issue Alvin wanted to talk about, and she could say "no" if she felt uncomfortable about the topic. Fortunately, Desi agreed to talk about the topic.

3. Dissociate speakers, hearer from the discourse

Instead of using 'you', Alvin used 'seorang Desi' several times to separate himself and Desi from the discourse.

(9) Alvin : Kapan seorang Desi itu pengen sendiri?

Desi : Biasanya pada saat saya capek kerja

(10) Alvin : Saya balik lagi ke mas Irwan ya? Di saat seorang Desi membutuhkan seorang sosok Irwan tapi malah sosok mas Irwan ini jarang ada waktu untuk Desi.

In these examples, Alvin acted as if 'seorang Desi' in his utterances was a different person from Desi who talked to him as the guest.

As has been explained on the the theoretical framework, in a talk show, hosts usually hold two different roles; as a close friend and as an outsider. In relation to the face wants, hosts could use positive or negative face to show their position towards the guests. In Just Alvin, the host most likely used positive face to show the closeness between the host and the guest. For example, Alvin complimented Desi to show the closeness between him and Desi and at the same time trying to make Desi comfortable.

Nevertheless, Alvin sometimes also used negative face utterances during the conversation. For example, he once used the word "kita" which set a separation between heas a host, and Desi- as a guest. In this situation, Alvin tried to ask something as an outsider 
who does not know anything about Desi and he expects Desi to be independent, in terms of

Desi should answer the question as if she does not know Alvin as her friend.

\section{Conclusion}

Based on the description above, it can be concluded that Alvin used positive face utterances to show that he knew what Desi had been through and understood her situations and feeling. Alvin put himself as a person who close to Desi and tried to give Desi a comfortable atmosphere of talking. However, there are times when Alvin used negative face to show that he is not totally part of Desi's life and he knew nothing about her. At these times, Alvin would expect Desi to explain as clear as possible.

\section{References}

Brown, Penelope and Stephen C. Levinson. 1987. Politeness: Some Universals in Language Usage. Cambridge: Cambridge University Press.

Bruun, Hanne. 1999. The Aesthetics of the Television Talk Show. Retrieved April 27, 2013 from http://www.carbonfarm.us/365/readings/bruun.pdf

Yule, George. 1996. Pragmatics. Oxford: Oxford University Press 